\title{
Potassium: Aldosterone Relationships in Pregnant Ewes and Chronically Cannulated Ovine Fetuses
}

\author{
E. M. WINTOUR, E. MARELYN, A. BARNES, F. CAHILL, K. J. HARDY, I. HORACEK, \\ AND B. A. SCOGGINS \\ Physiology Department, University of Melbourne, Parkville (E.M.W., A.B.), Austin Hospital-Department of Surgery, \\ University of Melbourne, (K.J.H.), Royal Womens Hospital, Carlton, (I.H.), Howard Florey Institute of Experimental \\ Physiology and Medicine, (E.M.W., B.A.S.), University of Melbourne, Australia
}

\section{Summary}

As maternal hyperkalemia quickly induces fetal hyperkalemia, it was decided to investigate the effect of small elevations of plasma $\left[\mathrm{K}^{+}\right]$on the peripheral blood aldosterone concentration in chronically catheterized ovine fetuses and to compare this response to that obtained in the adult ewe both pregnant and nonpregnant. For elevations of plasma $\left[\mathrm{K}^{+}\right]$of 0.1 to $0.3 \mathrm{mmole} /$ liter blood aldosterone concentrations were elevated by $6.7 \pm 4.9$ (9) $\mathrm{ng} / \mathrm{dl}$ in nonpregnant sheep, $6.3 \pm 5.0$ (6) in pregnant ewes, but only $0.3 \pm 1.7(4)$ in fetal sheep. For increments in plasma $\left[\mathrm{K}^{+}\right]$of 0.4 - 1.0 mmole/liter aldosterone increments in nonpregnant ewes were $9.5 \pm 4.5(4) \mathrm{ng} / \mathrm{dl}$ compared with $10.1 \pm 4.7(5)$ in pregnant ewes and $1.5 \pm 2.6(7)$ in fetuses. There was no obvious correlation between the age of the fetus and the response to increased plasma $\left[\mathrm{K}^{+} \mathrm{I}\right.$. In effect, the blood aldosterone concentration of the fetus was not elevated by increasing plasma $\left[\mathrm{K}^{+}\right]$.

\section{Speculation}

The ovine fetus is not able to cope with hyperkalemia by increasing blood aldosterone concentration. Until the fetus is close to term, hyperkalemia may jeopardize the pregnancy by causing placental hemorrhages. 
It has been reported that during experimentally-induced potassium deficiency in pregnant rats $(4,9)$ and bitches $(8)$ the fetus is substantially protected from hypokalemia at the expense of the mother. On the other hand, maternal hyperkalemia quickly induces fetal hyperkalemia. In all species studied so far an elevation in the plasma potassium of the adult elicits a number of compensatory mechanisms designed to lower the extracellular fluid potassium concentration (10) including an increase in aldosterone secretion, stimulation of insulin and glucagon secretion, and, in the long term, increased renal secretory capacity. The kidney of the chronically cannulated ovine fetus can excrete potassium in increasis elevated by aldosterone infusion (6) from at least 90 days gestation (term $147 \pm 5$ ). Increased plasma $K^{+}$concentration is a potent stimulus to aldosterone secretion in the non-pregnant sheep $(1,5)$. It was therefore decided to investigate the effect of concentration in chronically-catheterized ovine foetuses, and to compare this response to that obtained in the adult ewe both preg nant and non-pregnant.

\section{METHODS}

Animals: Five pregnant ewes of known mating dates were used for the studies on the adult sheep.

They were studied between 100-138 days of gestation and again, non -pregnant, after their lambs had been weaned. Seventeen experiments were performed on the chronically-cannulated fetuses of nine ewes of 109-145 days gestation. The fetuses had been cannulated with silastic cannulae in one carotid artery and one jugular vein (9) 10-50 days prior to the $K$ infusion experiment:

Experimental

Adult sheep: Two cannulae were introduced into the jugular veins twenty-four hours before the experiment commenced. Following collection of a control sample, $\mathrm{KCl}$, in isotonic saline, was infused at the rates of $4,8,12,16,24$ mol/h (for one hour at each rate), at the end of which time a blood sample was collected costerone and cortisol determinations.

Fetal sheep: $\mathrm{KCl}$, in isotonic saline, was infused at $0.4 \mathrm{mmol} / \mathrm{h}$ $(1 \mathrm{ml} / \mathrm{hr})$ or $1.6 \mathrm{mmol} / \mathrm{hr}(4 \mathrm{ml} / \mathrm{h})$ for two hours via the fetal venous cannulae, and carotid arterial blood samples collected
before and just prior to the conclusion of the infusion. At the same time as the control fetal sample was being collected a $25 \mathrm{ml}$ sample of maternal venous blood was also collected. $13 \mathrm{ml}$ of this sample was transfused to the fetus immediately after the collection of the control fetal sample, the rest was kept for blood steroid and plasma electrolyte measurements. The transfusion of maternal blood to the fetus has been shown previously not to alter significantly adrenal steroid concentrations in fetal blood or to harm the fetus in any other detectable way (z). Ten $m l$ of fetal blood was frozen immediately and kept at $-20 \% \mathrm{C}$ for steroid analysis, whilst $3 \mathrm{ml}$ was used to determine hematocrit and plasma sod-
ium and potassium concentrations. The second fetal blood sample ium and potassium concentrations. The second

In other acute experiments plasma $\left[\mathrm{K}^{+}\right]$was measured at four halfhourly intervals after commencement of a similar infusion and was significantly e! evated from 30 minutes until completion of infusion.

\section{Chemical}

Plasma sodium and potassium concentrations were determined in a Technicon Autoanalyser. Whole blood samples were assayed for aldosterone, corticosterone and cortisol by the double isotope specificity of the method for ovine fetal blood had been establish Specificity of the
-ed previousiy (2).

Statistical analysis

Results were compared using student's t'-test. RESULTS

The potassium infusions into the ewe raised plasma $\mathrm{K}^{+}$by $0.1-2.3$ mmol/1. The potassium infusions into the fetus ratised fetal plas$\mathrm{K}$ by 0.3 to $1.5 \mathrm{mmol} / 1$. The control plasma $\mathrm{K}$ in the nonpregnant ewe was $4.4 \pm 0.2$ (5) mmol/1 - mean \pm standard deviation number of samples) which is not different from that of the ewe blood aldosterone concentrations were not significantly different. blood aldosterone concentrations were not significantly different, being $3.8 \pm 1.6$ (5) $\mathrm{ng} / \mathrm{d}$ The control plasma $\mathrm{K}^{+}$in 17 plasma samples from fetuses $109-145$
days gestation was $4.4 \pm 0.5$ (17) mmol/l and peripheral blood days gestation was $4.4 \pm 0.5$ (17) $\mathrm{mmol} / \mathrm{1}$ and peripheral blood increasing plasma potassium concentrations on blood aldosterone concentrations in non-pregnant, pregnant and fetal sheep is shown concentrations in non-pregnant, pregnant and fetal sheep is show

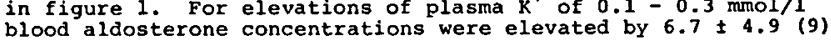
$\mathrm{ng} / \mathrm{dl}$ in non-pregnant sheep $6.3 \pm 5.0$ (6) in pregnant ewes but only $0.3 \pm 1.7$ (4) $\mathrm{ng} / \mathrm{dl}$ in fetal sheep. For increments in plasma on $\neq$ y $0.3 \pm 1.7$ of $0.4-1.0 \mathrm{ng} / \mathrm{dl}$ in fetal sheep. For increments in plas ewes were $9.5 \pm 4.5$ (4) $\mathrm{ng} / \mathrm{dl}$ compared with $10.1 \pm 4.7$ (5) in pregnant ewes and $1.5 \pm 2.6$ (7) in fetuses. Even greater increpregnant ewes and $1.5 \pm^{+} 2.6$ (7) in fetuses. Even greater increments in fetal plasma $K$ produced no change in plasma aldosterone of the foetus and the response in increased plasma $[K]$.

When responses in non-pregnant and pregnant ewes were compared it was seen that pregnancy did not alter the magnitude of the change in peripheral blognancy did not alter the the fetus was not elevated by increasing plasma [ $k]$.

Increases in plasma $\mathrm{K}^{+}$had no effect on peripheral blood values of corticosterone or cortisol in the non-pregnant or pregnant ewe, Table 1 , or in the fetus of less than 138 days of age but may have had an effect in the four fetuses of 138 days or more gestation $(P<0.05)$.

TABLE 1.

EFFECT OF INCREASED PLASMA $\left[\mathrm{K}^{+}\right]$ON BLOOD STEROID VALUES

$\frac{\text { Corticosterone }}{\mu \mathrm{g} / 100 \mathrm{ml} \text { blood }}$

Non-pregnant

ewe

Ewes 100-140 days pregnant

Fetuses 109-137 days gestation gestation
$0.09 \pm 0.06 \quad 0.08 \pm 0.05$

Control

$0.49 \pm 0.48 \quad 0.38 \pm 0.26$
$0.14 \pm 0.110 .12 \pm 0.09$

(5)

(20)

(5)

$0.03 \pm 0.03 \quad 0.03 \pm 0.03$

(13)
$0.04 \pm 0.05 \quad 0.15 \pm 0.08$

(4)
$1.33 \pm 1.29 \quad 3.0 \pm 2.2$
Effects of $\mathrm{K}^{+}$infusion on fetal well-being:

Three fetuses which each received 2 potassium infusions on or after the 136th day of gestation were born alive on day 146 and survived. Two fetuses which each received two potassium infusions at younger ages (117-136 days) died 1 or 4 days respectively afte the second potassium infusion and were aborted. Dally $\mathrm{pH}$ and blood gas analysis on fetuses showed no deviation from normal values until day of death. In two other fetuses which received their first infusion on days 109 or 134 were delivered alive by caesarian section 7 days later in order to study the placenta for potential pathological changes. Neither fetus lived after Table 2 shows the results for $\mathrm{pH}$ and $\mathrm{pCO}_{\text {during and after pot- }}$ Table 2 shows the results for $\mathrm{pH}$ and $\mathrm{pCO}_{2}$ during and after potand one which was delivered alive at 140 days (Keva).

TABLE 2.

EFFECT OF INTRAVENOUS POTASSIUM CHLORIDE INFUSION ON FOETAL

\begin{tabular}{|c|c|c|c|c|c|}
\hline Experiment & Time & Ver & ene & & \\
\hline \multicolumn{6}{|l|}{ FIRST INFUSION } \\
\hline I.v. $\mathrm{KCl} 0.4 \mathrm{mM} / \mathrm{L}$ & $\begin{array}{l}\quad 00 \\
+30 \text { mins } \\
+60 \text { mins } \\
+90 \text { mins } \\
+120 \text { mins }\end{array}$ & $\begin{array}{l}7.42 \\
7.44 \\
7.38 \\
7.38 \\
7.38\end{array}$ & $\begin{array}{l}41.6 \\
35.0 \\
37.1 \\
42.2 \\
33.0\end{array}$ & $\begin{array}{l}7.39 \\
7.39 \\
7.38 \\
7.37 \\
7.38\end{array}$ & $\begin{array}{l}37.8 \\
45.0 \\
36.2 \\
33.0 \\
35.0\end{array}$ \\
\hline \multicolumn{2}{|l|}{$\begin{array}{l}24 \mathrm{~h} \text { after } \\
\text { infusion ceased }\end{array}$} & 7.39 & 41.6 & 7.42 & 31.9 \\
\hline \multicolumn{2}{|l|}{$+48 h$} & 7.38 & 38.0 & 7.37 & 37 \\
\hline \multicolumn{6}{|c|}{ Second $K$ infusion } \\
\hline \multicolumn{2}{|l|}{$\begin{array}{l}+24 \mathrm{~h} \text { after } \\
\text { second infusion }\end{array}$} & \multicolumn{2}{|c|}{ Lamb dead } & 7.42 & 38 \\
\hline & 7.42 & 37.5 \\
\hline \multicolumn{4}{|l|}{$+72 h$} & \multicolumn{2}{|c|}{$\begin{array}{l}7.42 \quad 45.0 \\
\text { Live lamb delivered } \\
\text { placental deter- } \\
\text { ioration observed. }\end{array}$} \\
\hline
\end{tabular}

In the placenta of the two sacrificed fetuses approximately one quarter of the cotyledons showed evidence of haemorrhage which appeared to originate in the hylar region at the site of insertion of fetal vessel into the cotyledon. In the more advanced cases the blood extravasated from the hylum over the surface of the cotledon and spread under the membranes towards the uterine wall. Microscopically the haemorrhages were multifocal occurring within the first two millimetres of the foetal surface immediately adjacent to the hylum. There was a tendency for confluence and extrathere over the surface of the cotyledon. The large foetal vesse1s
were intact and the remainder of the cotyledon was normal. There were no general haemorrhagic changes within the cotyledon. The position, size and number of the haemorrhages suggest that they position, size and number of the haemorrhages suggest that they than capillaries or arteries and veins.

\section{DISCUSSION}

Increasing plasma $\left[\mathrm{K}^{+}\right]$in the ewe during the last third of pregnancy produced similar elevations in peripheral blood aldosterone concentration to those seen in the non-pregnant ewe. It has already been reported that peripheral blood concentration of aldoready been reported that peripheral blood concentration of aldosterone, cortisol and corticosterone are similar in pregnant and
non-pregnant sheep. In contrast is the relatively poor response to infused potassium in the fetus. There are at least two pos ble explanations for this: (a) the fetal adrenal is relatively insensitive to variations in plasma $[K]$, or (b) most of the aldo sterone in the fetal circulation originates from the mother by trans-placental passage, and a significant alteration in the fetal blood concentration to such a large extent. Preliminary results 
iuggest up to 508 of the fetal aldosterone may come from the other prior to 130 days but that more than 808 is of fetal adren 1 origin thereafter (Wintour - unpublished results). This then eaves us with the conclusion that the fetal adrenal is relatively $\left[\mathrm{K}^{+}\right.$]

'his would confirm previously reported work on fetal adrenal secetion in acute preparations, and on in vitro incubation studie 11) In this earlier study adrenals from fetuses of less than 20 days gestation were incubated in a buffer containing [ $K$ ] a mmol/ 1 and no effect on aldosterone was measured, although in $k$ l is $K$ is outside the normal physiological range achieved in the resent paper. It is interesting to note that in the previous on on in acutely cannulated fetuses the adrenal secretion rate of orticosterone and cortisol secretion rates were similarly elevat d, which correlates with an increased peripheral blood value of zorticosterone and cortisol in fetuses of 138 days gestation in the present series.

The death of two fetuses following potassium infusions, and the pathological changes in the placenta of the two fetuses which were lelivered by caesarian section suggest that hyperkalemia may be langerous to the pregnancy. Whilst the effects cannot be assignd, unequivocably, to the potassium experiment, it is worthwhile to note that in at least thirty other chronically cannulated fetsses in this laboratory, no such placental changes or deaths have rccurred. These other fetuses have been subjected to repeated zxperimentation, involving collection of fetal blood, transfusion of maternal blood, and infusion of substances such as aldosteron (6), antidiuretic hormone (7) and ACTH (2). The survival of the loer fetuses could be due to the elevation of survival of the corticostas could be due to the elevation of blood cortisol and their survival may have been due to the fact that they were born jefore placental damage had occurred. In conclusion, were born infused into the fetal circulation of chronically cannulated ovin Eetuses does not produce significant increments in fetal peripheril blood aldosterone concentration, and may cause abortion after $1-5$ days, dependent on the level of placental haemorrhage.

\section{REFERENCES}

Blair-West, J.R., Coghlan, J. P., Denton, D. A. Goding, J. R., Nunro, J. A., Peterson, R. E., and Wintour, Marelyn.: Humoral stimulation of adrenal cortical secretion. J. Clin. Invest. 41 : 1606 (1962).

- Brown, Elizabeth H., Coghlan, J. P., Hardy, X. J., and Wintour E. Marelyn.: Aldosterone, corticosterone, cortisol,11-deoxycorticosterone, 11-deoxycortisol concentrations in the blood of chronically-cannulated ovine foetuses. Acta Endocrin. (Kbh) 64 (1978)

- Coghlan, J. P., and Scoggins, B. A. : Measurement of aldosterone in peripheral blood of man and sheep. J. Clin. Endocrin., $27: 1470 \cdot(1967)$

- Dancis, J. and Springer, Dawn.: Fetal Homeostasis in maternal malnutrition : Potassium and sodium deficiency in rats. Ped. Res., 4 : 345 (1970).

- Funder, J. W., Blair-West, J. R., Coghlan, J. P., Denton, D.A. Scoggins, B. A., and Wright, R. D.: Effect of Plasma $\left[K^{+}\right]$on the secretion of aldosterone. Endocrinol., 85 : 381 (1969).

- Lingwood, B. L., Coghlan, J. P., Hardy, K. J., and Wintour, E. M.: Effect of aldosterone on urine composition in the chroni-
cally-cannulated ovine foetus. J. Endocrinol., $76: 553$ (1978)

'opyright $\odot 1979$ International Pediatric Research Foundation, Inc. $031-3998 / 79 / 1304-0265 \$ 02.00 / 0$
7. Lingwood, Barbara, Hardy, K. J., Horacek, I., McPhee, M.I., Scoggins, B. A. and Wintour, E. Marelyn.: The effect of antidiuretic hormone on urine flow and composition in the chronically-cannulated ovine fetus. Quart. J. Exp. Physiol.,
63 : 315 (1978).

8. Serrano, C. V., Talbert, L. M., and Welt, L. G.: Potassium deficiency in the pregnant dog. J. Clin. Invest., $43: 27$ $(1964)$.

9. Stewart, E. L. and Welt, L. G.: Protection of the fetus in 824 (1961).

10.stockigt, J. R.: Review - Potassium homeostasis. Aust. \&.2. J. Med., $7: 66$ (1977).

11.Wintour, E. Marelyn, Brown, Elizabeth H., Denton, D. A., Hardy, K. J., McDougall, J. G., Oddie, Catherine J., and Whipp, G. T. The ontogeny and regulation of corticosteroid secretion by the ovine foetal adrenal - In vitro and in vivo studies. Acta
Endocrinol. (Kbh.), 79 : 301 (1975).

12. Wintour, E. Marelyn, Blair-West, J. R. Brown, Elizabeth, J. Coghlan, J. P., Denton, D. A., Nelson, J., Oddie, C. J., Scoggins, B. A., Whipp, G. T. and Wright, R. D.: The effect of pregnancy on mineralo - and gluco-corticoid secretion in the sheep. clin. Exp. Pahrm. Physiol., $3: 331$ (1976).

13. Received for publication $6 / 8 / 78$.

14. Accepted for publication $12 / 6 / 78$.

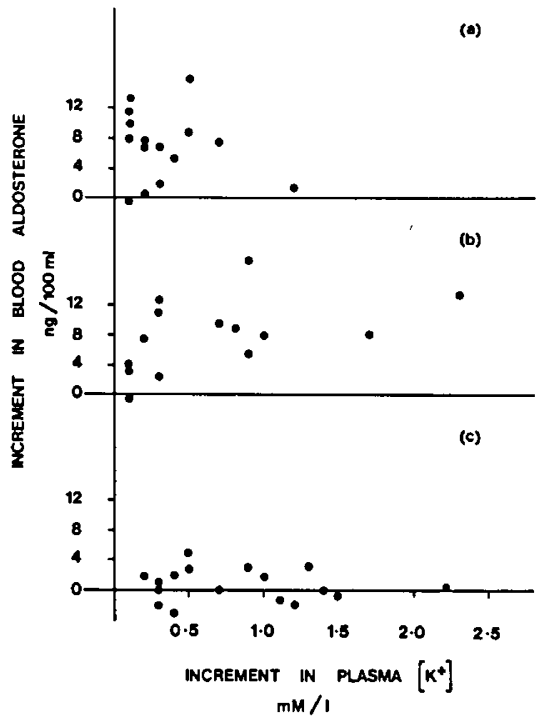

Figure 1. Increment in blood aldosterone concentrations, with ateration in plasma $\left[\mathrm{K}^{+}\right]$in (a) non-pregnant ewes ovine fetuses between 109 and 145 days of gestation.

Printed in U.S.A. 